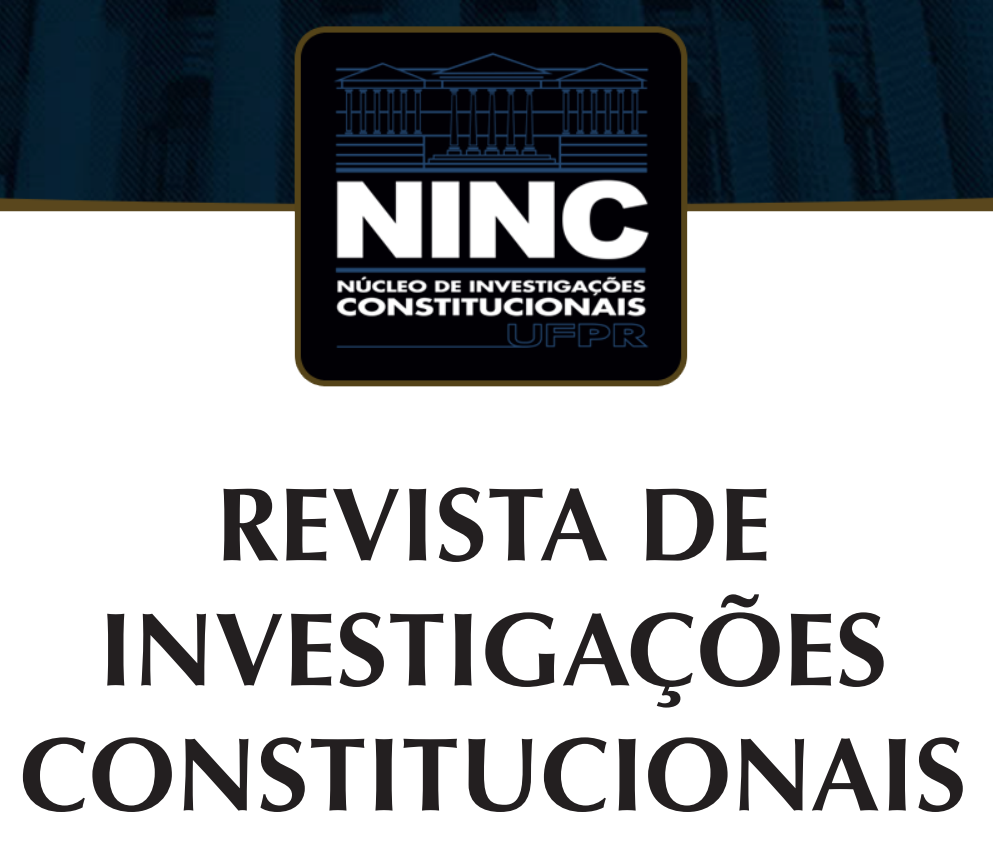

JOURNAL OF CONSTITUTIONAL RESEARCH

vol. 8 | n. 1 | janeiro/abril 2021 | ISSN 2359-5639 | Periodicidade quadrimestral Curitiba | Núcleo de Investigações Constitucionais da UFPR | www.ninc.com.br 


\title{
Interpretative skepticism and constitutional interpretation: a criticism of Brazilian constitutional court decision
}

\section{Ceticismo interpretativo e interpretação constitucional: uma crítica à decisão da Corte Constitucional brasileira}

\author{
MARTHA TORIBIO LEÃO ${ }^{1, *}$ \\ ' Universidade Presbiteriana Mackenzie (São Paulo, São Paulo, Brasil) \\ marthatleao@gmail.com \\ https://orcid.org/0000-0003-3300-6591 \\ Recebido/Received: 25.10.2019 / October $25^{\text {th }}, 2019$ \\ Aprovado/Approved: 26.06 .2020 / June $26^{\text {th }}, 2020$
}

Abstract

This paper is a critical analysis of a recent case decided by the Brazilian Constitutional Court, which can be considered as paradigmatic of the current approach of Brazilian case law with reference to constitutional interpretation. The case regards the unconstitutionality of a statute provision which allowed the enforcement of penalties pending a second instance appeal and therefore before res judicata. This analysis aims at discussing the concept of constitutional provisions and legal interpretation theory as well as the legal arguments applied in these cases. The approach endorsed by the Court will be argued from both a theoretical point of view and a political standpoint, in order to outline its inadequacy and conflict with the Rule of Law doctrine.

Keywords: interpretative skepticism; constitutional in terpretation; Constitutional Court; defeasible principles; indefeasible rules.
Resumo

Este artigo é uma análise crítica de um caso recente decidido pelo Supremo Tribunal Federal, que pode ser considerado paradigmático da atual abordagem da jurisprudência brasileira com referência à interpretação constitucional. $O$ caso refere-se ao julgamento de constitucionalidade acerca da execução de sanções pendentes de recurso de segunda instância e, portanto, antes do trânsito julgado. Esta análise visa discutir o conceito de disposições constitucionais e a teoria da interpretação legal, bem como os argumentos legais aplicados nesses casos. A abordagem adotada pelo STF será discutida tanto do ponto de vista teórico quanto do ponto de vista político, a fim de delinear sua inadequação e conflito com a doutrina do Estado de Direito.

Palavras-chave: ceticismo interpretativo; interpretação constitucional; Tribunal Constitucional; derrotabilidade de princípios; iderrotabilidade de regras.

Como citar esse artigo/How to cite this article: LEÃO, Martha Toribio. Interpretative skepticism and constitutional interpretation: a criticism of Brazilian constitutional court decision. Revista de Investigações Constitucionais, Curitiba, vol. 8, n. 1, p. 135-160, jan./abr. 2021. DOI: 10.5380/rinc.v8i1.69875.

* Professora de Direito Tributário da Universidade Presbiteriana Mackenzie (São Paulo-SP, Brasil). Doutora e Mestre em Direito Tributário pela Universidade de São Paulo. Mestre em Teoria do Direito e Democracia Constitucional pelo Istituto Tarello per la Filosofia del Diritto/Università Degli Studi di Gênova. E-mail: marthatleao@gmail.com. 
Regardless of whether the matter is understood in such a narrow way, it is obvious that no democratic Constitutional State can sacrifice predictability on the altar of flexibility and case-based reasonability. Flexible regulations, their large-scale application and "soft" interpretation jeopardise predictability. Law stops being law and primarily becomes the delivery of "reasonability".

Due process is severely jeopardized if the end justifies the means. ${ }^{2}$

\section{CONTENTS}

1. Introduction; 2. Interpretive skepticism and constitutional provisions; 2.1 . The need for interpretation; 2.2. The skeptical theory of interpretation; 2.3. The characteristics of the Brazilian Constitutional System; 3. The application of the skeptical theory of interpretation to the jurisprudence of the Brazilian Constitutional Court; 3.1. Case study: Execution of the sentence after condemnation in the second instance; 3.1.2. The arguments of interpretation applied in the Court's decision; 3.1.3. Criticism of the decision; 4. Conclusions; 5 . References.

\section{INTRODUCTION}

This paper aims to propose a critical analysis of the case law of the Brazilian Constitutional Court, especially regarding the interpretation of constitutional provisions establishing rules. Unlike other countries which have Constitutions that are more synthetic, the Brazilian Constitution is characterized by its great extension and by establishing specific and detailed rules regarding behaviors that must be adopted to achieve the purposes and goals determined therein. Within the many distinctive criteria proposed in order to distinguish rules and principles, we adopt in this work the criterion proposed by Barberis and Ávila: legislative rules directly regulate citizens' conduct, whereas constitutional principles regulate only that of legislators. ${ }^{3}$. The preference for rules over principles has an important function in each system, which cannot be disregarded. In this sense, rules are an important component of the Rule of Law doctrine, insofar as they protect against arbitrariness and allow individuals to plan their affairs knowing in advance what the consequences of their acts will be. ${ }^{4}$ Though legal

AARNIO, Aulis. Essays on the Doctrinal Study of Law. Dordrecht: Springer, 2011. p. 163.

2 SEER, Roman. National Report: Germany. In: MEUSSEN, Gerard. (Org.). The Burden of Proof in Tax Law: EATLP International Tax Series, volume 10. Uppsala: EATLP, 2011. p. 127-139 (128).

3 BARBERIS, Mauro. Una filosofia del Diritto per lo stato costituzionale. Torino: G. Giappichelli Editore, 2017. p. 91; ÁVILA, Humberto. Teoria dos Princípios. 18. ed. São Paulo: Malheiros, 2018. p. 102. The standard distinction is different: cf. ALEXY, Robert. Theorie der Grundrechte. 3 ed. Frankfurt am Main: Suhrkamp, 1996. p. 75 e ss.

4 FALLON, JR. Richard H. "The Rule of Law" as a Concept in Constitutional Discourse. Columbia Law Review, New York, vol. 97, n. 1, p. 1-56, 1997. p. 7-8. 
theorists may disagree on the implications of prescribing rules and establishing legal principles, the present paper takes the view that when legislation uses rules rather than principles or standards, it defines how a purpose or goal should be promoted. In this sense, rules differ from principles precisely because they anticipate the weight of values that could be in conflict in a given situation. By providing in advance for the resolution of such conflict, rules form a directive that already includes how the plurality of values of that system should be promoted in that specific situation.

Therefore, it is not the role of the court to reconsider these values by weighting them in the concrete case at hand. If the court were to do so, it would make rules useless, since it would deprive them of one of their main functions, namely, setting in advance how conflicts should be solved. This is why norms that take the form of rule protect individuals against the arbitrariness of courts. As Jhering pointed out in a rather widespread passage of his doctrine, "Form is the twin sister of liberty, and the sworn enemy of arbitrariness", it functions as an instrument of protection against "external threats", since "rigid forms are the school of discipline and order". It is in the context of a constitution characterized by rules that trials by the Brazilian Constitutional Court will be analyzed.

In the first part, from a theoretical point of view, the skeptical theory of interpretation (in its radical and moderate aspects) will be analyzed, as well as the peculiar characteristics of the Brazilian Constitution, which uses rules, not principles, to prescribe fundamental rights. In the second part, the following constitutional judgments will be examined and discussed: the case regards the unconstitutionality of a statute provision which allowed the enforcement of penalties pending a second instance appeal and therefore before res judicata (BRAZIL, Supreme Federal Court, Constitutional Declaratory Actions - ADCs n. 43 and 44, Justice Edson Fachin (Relator), Plenary Court, 05/10/2016). The constitutional provisions applicable to this case and the arguments of interpretation used by the Justices in the judgment will also be critically examined. This case is paradigmatic of Brazilian Constitutional case law because the literal interpretation of provisions as a rule was derogated by constitutional principles considered more important by the Supreme Federal Court.

The purpose of this paper is to demonstrate that the Justices of the Brazilian Constitutional Court have departed from their roles as interpreters in order to impose their vision of justice on the Constitutional System. The Brazilian framers, however, did not authorize the Judiciary Branch to act in such a manner, since in respect to some subjects, the framers used rules, instead of principles or general standards, to prescribe what conduct should be adopted. By trying to impose their own views as if they were

5 JHERING, Rudolph von. Geist des römischen Rechts auf den verschiedenen Stufen seiner Entwicklung. 5. ed. Leipzig: [s.n.], 1880. p. 471. 
the norms prescribed by the Constitution, the Justices of the Brazilian Supreme Court act in a manner contrary to the Rule of Law doctrine and to the ideals prescribed by the legal certainty principle.

\section{INTERPRETIVE SKEPTICISM AND CONSTITUTIONAL PROVI- SIONS}

\subsection{The need for interpretation}

To interpret is to assign meaning to a normative text and, therefore, interpretation does not depend on the existence of contingent doubts or controversies, because any normative text must be interpreted to have a meaning. According to Guastini, there is no meaning without interpretation and, consequently, there is no application without interpretation. ${ }^{6}$ The term interpretation refers both to the activity that consists in determining the meaning of particular words, phrases or complete utterances (interpretation as activity) as well as the result of this activity (interpretation as product). ${ }^{7}$ "Interpretation" as an activity is a mental process and "interpretation" as a product of such activity is a discourse. ${ }^{8}$

Although the starting point of interpretation is the text, problems related to the attribution of meaning to legislative formulations are numerous. First, there is the problem of ambiguity (one is not sure whether provision $\mathrm{P}$ establishes norm N1 or norm N2). Second, there is the problem of complexity (from provision P one can state norm $\mathrm{N} 1$ and norm N2). Third, there is the problem of implication (from provision $\mathrm{P}$ one can state norm N1 and norm N1 implies norm N2). And fourth, there is the problem of defectiveness (from provision $P$ one can state norm $N$, according to which "if $A$, then $B$, unless $X^{\prime \prime}$ ). All these problems demonstrate that provisions do not have a single meaning that can be simply stated by the interpreter, nor several meanings that can be easily grasped. ${ }^{9}$ The natural language in which Law is conceived is characterized by different phenomena that necessarily impose a "creative interpretation" to define the concrete and determinate consequences of a norm in specific contexts. ${ }^{10}$ According to Chiassoni,

6 GUASTINI, Riccardo. Interpretar y argumentar. Madrid: Centro de Estudios Políticos y Constitucionales, 2014. p. 342-343.

7 GUASTINI, Riccardo. Interpretar y argumentar. Madrid: Centro de Estudios Políticos y Constitucionales, 2014. p. 202-203.

8 GUASTINI, Riccardo. Interpretación y construcción jurídica. Legal Interpretation and Legal Construction. Isonomía, [s.l.] n. 43, p. 11-48, out. 2015. p. 13.

9 ÁVILA, Humberto. Função da Ciência do Direito Tributário: do formalismo epistemológico ao estruturalismo argumentativo. Revista Direito Tributário Atual, São Paulo, vol. 29, p. 181-204, 2013, p. 190-191.

10 MENÉNDEZ, José Augustín. Justifying Taxes - some elements for a General Theory of Democratic Tax Law. Dordrecht: Kluwer Academic Publishers, 2001, p. 14; 72. 
textual interpretation is an activity composed by two related operations: first, a syntactic analysis of the legal provision, and, secondly, a semantic-pragmatic interpretation of the legal provision. It is an activity with a practical function, which must be adopted for several reasons. ${ }^{11}$ Like any other normative text, constitutional provisions present problems related to the attribution of meaning to texts and depend on the interpretation to be applied. The interpretation of the text of any constitution is an intellectual activity that intends to assign a meaning to a constitutional provision. ${ }^{12}$

There is, however, no consensus regarding the interpretive techniques and methodology that should be used by constitutional courts to carry out this activity. At least three theories must be examined: cognitive theory, radical skeptical theory and moderate skeptical theory. The present paper takes the view that each of these theories is closely related to a particular method of interpreting provisions and thus assigning meaning to normative texts.

\subsection{The skeptical theory of interpretation}

Before explaining what the skeptical theory of interpretation is, it is necessary to contrast it with the cognitive theory of interpretation. On one hand, the cognitive theory of interpretation holds that the interpretation of the normative texts would require that the interpreter's activity be bound to knowledge and not to will. Such a theory of interpretation is related to the idea that the interpreter could and should only describe, report or discover pre-existing meanings. According to this view, the content of Law would be objective, pre-constituted and susceptible to knowledge by the interpreter, who would only describe or declare it. This concept assumes that the activity of the interpreter is merely identifying the meaning of the norm because such meaning is univocal, pre-constituted and susceptible of being known. ${ }^{13}$

Such activity would be analogous to the definition of information, in the sense of recognizing the effective linguistic use of a term. ${ }^{14}$ It is simply the activity of identifying, in a normative text, the different possible meanings (from rules of language, the interpretive techniques in use, and the available dogmatic theses), without deciding which of these possible meanings would be the right one. ${ }^{15}$

\footnotetext{
11 CHIASSONI, Pierluigi. Tecnica dell'interpretazione giuridica. Bologna: Il Mulino, 2007, p. 52-53.

12 CHIASSONI, Pierluigi. Tecnica dell'interpretazione giuridica. Bologna: Il Mulino, 2007, p. 154.

13 MAZZARESE, Tecla. Enunciato descritivo d'una norma: osservazione su uma nozione imbarazzane. Studi in memoria de Giovanni Tarello, Milano, vol. 2, p. 253-288, 1990, p. 270.

14 GUASTINI, Riccardo. Interpretar y argumentar. Madrid: Centro de Estudios Políticos y Constitucionales, 2014, p. 48.

15 GUASTINI, Riccardo. Interpretar y argumentar. Madrid: Centro de Estudios Políticos y Constitucionales, 2014, p. 45.
} 
According to Ávila, the interpretation of the cognitivist theory would comprise only acts of knowledge in the strict sense and never acts of will: interpretation would not involve the choice of a meaning, but rather the mere theoretical judgment of apprehending objective and pre-constituted meaning. This theory, therefore, presupposes a univocal meaning, created by the authority who issued the provision, and one which is susceptible of being known by the interpreter: since there would be only one meaning, only one interpretation would be true. In other words, the activity of the interpreter would always be descriptive and, therefore, never ascriptive or constructive of meaning. ${ }^{16}$

On the other hand, the skeptical theory of interpretation holds that the activity of interpretation includes both acts of will and knowledge or solely acts of will, so that the Law is (re)created by the interpreter and not (only) by the authority that issued it. ${ }^{17}$ Thus, it is clear that the skeptical theory of interpretation is based on different premises from the ones underlying the cognitive theory. The skeptical theory of interpretation can be divided into two strands: radical skepticism and moderate skepticism.

Radical skepticism understands that normative texts have no meaning before interpretation: meaning does not pre-exist interpretation, it results from it. This means that judges are totally free to assign any meaning to any normative text. Interpretation, according to this theory, would involve only acts of will since any meaning could be assigned to a given provision. In other words: provisions would admit multiple meanings and the interpreter would be free to choose any one of them. As Ávila points out, in this case the activity of the interpreter is always ascriptive, choosing any meaning as being the correct one. ${ }^{18}$ As noted by Guastini, in some sense, there would not even be Law before interpretation: "normative texts are not exactly Law, but only sources of Law. All Law, in this sense, is created not by legislators, but by interpreters and only by them."19

Such a skeptical stance empties legality of any meaning or purpose. If meanings are always created and constructed by the interpreter, and the text or the provision does not offer any type of limit to this activity, the guarantee of legality becomes useless and innocuous in its role of guaranteeing legal certainty: the applicable rule, after all, will be the one defined by the will of the interpreter. This skeptical stance results in admitting that the text is empty and does not even serve as a frame for interpretation. There is, in this model, space for the flexibility of the interpreter to act according to

\footnotetext{
16 ÁVILA, Humberto. Função da Ciência do Direito Tributário: do formalismo epistemológico ao estruturalismo argumentativo. Revista Direito Tributário Atual, São Paulo, vol. 29, p. 181-204, 2013, p. 185.

17 ÁVILA, Humberto. Função da Ciência do Direito Tributário: do formalismo epistemológico ao estruturalismo argumentativo. Revista Direito Tributário Atual, São Paulo, vol. 29, p. 181-204, 2013, p. 185.

18 ÁVILA, Humberto. Função da Ciência do Direito Tributário: do formalismo epistemológico ao estruturalismo argumentativo. Revista Direito Tributário Atual, São Paulo, vol. 29, p. 181-204, 2013, p. 185.

19 GUASTINI, Riccardo. Interpretar y argumentar. Madrid: Centro de Estudios Políticos y Constitucionales, 2014, p. 352.
} 
his or her interests and his or her own reasonableness. As pointed out by Aarnio, in these instances, Law ceases to be Law and becomes something like the "delivery of reasonableness".20 Based on these arguments, therefore, such a stance is criticized, for example, by Diciotti, for whom the extreme version of skepticism would be the same as arguing that judges could establish anything as a result of the interpretive activity, and, by extension, as the meaning of a legislative statement. ${ }^{21}$

Moderate skepticism understands that interpretation merges acts of knowledge and will and encompasses the choice of a meaning among the various ones admitted by a text. Here, the activity of the interpreter is both descriptive and ascriptive: descriptive, for identifying the various possible meanings of a legal provision; and, ascriptive, for choosing one of them as being correct. ${ }^{22}$ The institution of a rule postulates greater rigidity, inflexibility and intransigence than reasons not crystallized in its hypothesis. ${ }^{23}$ Although meanings must be reconstructed from a provision, there is an intersubjectively consensual meaning capable of communicating prescriptive content, even if this content could be perfected in the application of the rule. ${ }^{24}$ In other words, there is a meaning prior to interpretation.

At this point, there is a difference in relation to the posture adopted by Guastini The Italian author refers to himself as a moderate skeptic, although some of his stances (and some on the part of his critics) reveal him to be a radical skeptic. The characterization of Guastini as a radical skeptic stems from his emphatic defense that interpretation is always decisive and often creates new norms from the interpreter's construction of meanings, as well as the idea that meaning does not pre-exist interpretation. ${ }^{25}$ According to Guastini, a norm is the meaning of the normative text and, therefore, always presupposes interpretation. In his words, "any normative proposition - as a proposition (true or false) that affirms the existence (in any sense) of a juridical norm within a given juridical order - presupposes an interpretative decision".26 The Italian author, however, considers himself as a moderate skeptic, in the sense that it is one thing to say that normative texts have a plurality of possible meanings - and therefore admit a plurality of interpretations - and another thing to say that they do not have any meaning - and

20 AARNIO, Aulis. Essays on the Doctrinal Study of Law. Dordrecht: Springer, 2011, p. 163.

21 DICIOTTI, Enrico. L'ambigua alternativa tra cognitivismo e scetticismo interpretativo. Working Paper 45, Università degli studi di Siena, Siena, p. 3-81, 2003. p. 12-13.

22 ÁVILA, Humberto. Função da Ciência do Direito Tributário: do Formalismo Epistemológico ao Estruturalismo Argumentativo. Direito Tributário Atual, São Paulo, n. 29, p. 181-204, 2013. p. 185.

23 ÁVILA, Humberto. Certainty in Law. Dordrecht: Springer, 2016. p. 438.

24 RAMÍREZ, Federico Arcos. La seguridad jurídica: una teoría formal. Madrid: Dykinson, 2000. p. 230.

25 GUASTINI, Riccardo. Interpretar y argumentar. Tradução de Silvina Álvarez Medina. Madrid: Centro de Estudios Políticos y Constitucionales, 2014. p. 351.

26 "Qualsivoglia proposizione normativa - intesa come proposizione (vera o falsa) che asserisce l'esistenza (in qualche senso) di uma norma giuridica entro um dato ordenamento - sembra presupporre uns decisione interpretativa" (GUASTINI, Riccardo. Nuovi studi sull'interpretazione. Roma: Aracne, 2009, p. 59). 
therefore admit any interpretation. ${ }^{27}$ In addition, previous interpretations create links to new interpretations. This means that the author does not deny that already stabilized interpretations create limitation for the interpreter, although he maintains that the meaning always depends on interpretation. In other words, texts are, over time, objects of processes of cognition that form minimal meanings or nuclei of meaning that are objects of consensus: this is a limit to interpretation.

The skeptical theory of interpretation is criticized precisely in terms of the freedom that would be granted to the interpreter regarding the definition of Law. If the interpreter is not limited by the preliminary meaning of the text, what is the guarantee granted by Law, in the sense of positive Law? Has Law, in the sense of formal and material limitations to the exercise of power, lost its space? Laporta acknowledges this crisis and concludes that there is a need to reaffirm the role of Law. Laporta argues that one must remember that the most important and decisive nucleus of the juridical order is composed by a coherent body of general and abstract norms to which a privileged deference must be granted. Ultimately, he defends "less constitutionalism and more neocodification." ${ }^{28}$ In this sense, it is fundamental to reestablish the role of Law and the importance of the limitation imposed by the text. For these reasons, the author defends a text-oriented interpretation, insofar as it has an autonomous meaning that depends, above all, on the conventions of the use of words in a certain community. Meaning cannot be given by the reader of the text, that is, by its interpreter, because otherwise the entire idea of the Rule of Law would "escape between the fingers". ${ }^{29}$ As Schauer points out, disregarding the text as a starting point is to disregard a very important aspect of the very nature of law. ${ }^{30}$ Such an understanding could lead to the extreme of understanding that the legislator produces formulations or dispositions (but not norms), while the interpreter (as the judge), by assigning meaning to these formulations, would be the true creator of the norms. According to this vision, it is not possible to say that the judge is subject to the norm since he or she is the creator of the norm. Such a construction, however, would lead to the ruin of the idea of Rule of Law. ${ }^{31}$

These conclusions are also reached by MacCormick when analyzing the consequences of a theory of judicial correction based only on the authority of the author of the decisions. According to the author, if the correctness of a decision depends only on the authority of the one issuing it, this would result in the idea that judges become, in a pure sense, political actors, that is, people who decide what Law is based on their own

27 GUASTINI, Riccardo. Interpretar y argumentar. Tradução de Silvina Álvarez Medina. Madrid: Centro de Estudios Políticos y Constitucionales, 2014. p. 352.

28 LAPORTA, Francisco J. El Império da la Ley - Una visíon actual. Madrid:Trotta, 2007. p. 167.

29 LAPORTA, Francisco J. El Império da la Ley - Una visíon actual. Madrid: Trotta, 2007. p. 178-179.

30 SCHAUER, Frederick. Thinking like a lawyer: a new introduction to legal reasoning. Cambridge: Harvard University Press, 2009. p. 158.

31 LEAO, Martha. O Direito Fundamental de economizar tributos. São Paulo: Malheiros, 2018. p. 46. 
opinions and on things that are relevant to them. This would also mean that there is no law other than the one decided in cases that come before the courts. ${ }^{32}$ MacCormick points out that, in terms of sociology or political theory, this conclusion would result in the existence of a Judicial Power placed at the forefront of the political process of making Law: legal correction would be what judges say and that would be all there is to it. In this case, judges "would be law-makers as law-savers." ${ }^{33}$ These considerations demonstrate why there must be normativity prior to interpretation that binds, controls and limits the power of the interpreter when acting within the law. Interpretation, in this sense, presupposes a meaning and does not assign a meaning. Indeed, interpretation is interpretation of meaning, not interpretation of an enigmatic syntactic formulation that means nothing until the interpreter exercises some "magical function" upon it. ${ }^{34}$ It is clear, however, that the debate about interpretation cannot be oversimplified. MacCormick notes that there are different objects to be interpreted in Law, there are different interpretive perspectives, and there are appropriate interpretation arguments for different objects. Interpreting utterances, for example, is different from interpreting precedents, just as interpreting the Constitution is different from interpreting an agreement. And, especially, interpreting an entire practice of Law is not the same as interpreting any of its parts. ${ }^{35}$

There are sectors that require a greater degree of determinability of conduct in order to guarantee legal certainty to those individuals who participate in them as well as to conform to the Rule of Law doctrine. This requirement is directly related to the establishment of limitation on fundamental rights. The greater the limitation on fundamental rights, the greater the requirement for legal certainty and the necessity to control the arbitrariness of decisions, as occurs, for example, in Criminal Law and Tax Law. The greater the intensity of the restriction of the fundamental rights of freedom, property, and equality, the greater the requirement of determinability. ${ }^{36}$ However, this is not the same requirement that exists in Private Law, as in the regulation of contracts, for example. In this area, a system of concretion is allowed and adopted, in which the terms will be defined during their application. For example, the term good faith may be defined by interpretation because the exercise of freedom is regulated and not limited directly. ${ }^{37}$

\footnotetext{
32 MACCORMICK, Neil. Rhetoric and the Rule of Law: A Theory of Legal Reasoning. Oxford: Oxford University Press, 2005. p. 275.

33 MACCORMICK, Neil. Rhetoric and the Rule of Law: A Theory of Legal Reasoning. Oxford: Oxford University Press, 2005. p. 275.

34 LAPORTA, Francisco J. El Império da la Ley - Una visíon actual. Madrid:Trotta, 2007. p. 181-182.

35 MACCORMICK, Neil. Rhetoric and the Rule of Law: A Theory of Legal Reasoning. Oxford: Oxford University Press, 2005. p. 139-140.

36 RAMÍREZ, Federico Arcos. La seguridade jurídica: uma teoria formal. Madrid: Dykinson, 2000. p. 263.

37 ÁVILA, Humberto. Eficácia do Novo Código Civil na Legislação Tributária. In: GRUPPENMACHER, Betina. (Org.). Direito Tributário e o Novo Código Civil. São Paulo: Quartier Latin, 2004. p. 61-79 (78).
} 


\subsection{The characteristics of the Brazilian Constitutional System}

There are several unique features of the Brazilian legal order that must be considered for the object of this paper. Compared with other constitutions, the Brazilian Constitution is extensive, rigid and detailed. First, the Brazilian Constitution is extensive because it has 250 articles, many of which are composed of different numbers and letters. Those articles deal with individual rights and guarantees, social rights, the organization of the Federal State, the Public Administration, the Military, the organization of the Legislative, Executive, and Judicial Branches, the tax system, the sharing of revenue among the federation, and many other subjects. Second, the Brazilian Constitution is rigid because in accordance to article 60, paragraph 2, any proposal to modify the Constitution "shall be discussed and voted upon in each House of the National Congress, in two readings, and shall be approved only if it obtains, in both readings, three-fifths of the votes of respective members". And third, the Brazilian Constitution is detailed because it prescribes a myriad of specific provisions whose aim is to guide the conduct of individuals and the State.

The extension, rigidity, and high specification do not necessarily imply that constitutional provisions are and should be construed as entrenched, indefeasible clauses, unsusceptible of possible implicit exceptions. However, by analyzing the Brazilian Constitution as a whole, it is clear that these three features do not leave much room for determining how a provision should be construed. In other words, considering that the act of interpretation presupposes a text to which meaning will be attributed, it is not possible to completely disregard how the Constitution is written. In this sense, the combination of these three elements (extension, rigidity and high specification of the constitutional provisions), in the Brazilian context, support the conclusion that many provisions set up in the Brazilian Constitution must be reconstructed as rules, otherwise many of its prescriptions would simply be irreconcilable and lead to interpretations contrary the core values of the Constitution itself.

Another example of the unique features of the Brazilian legal order can be found in the normative foundations of the legal certainty principle. On one hand, the legal certainty principle can be reconstructed by reference to direct provisions, such as article 5, caput, of the Constitution. On the other hand, the reconstruction of the legal certainty principle at the constitutional level is also supported by the combination of different constitutional provisions, which implicitly aim at protecting it. Just to give an example, the Constitution states that no tax law shall have retroactive effects. By prohibiting the retroactivity of tax laws, the norm reconstructed from this provision aims at protecting taxpayers' predictability of the tax system, in the sense that every taxpayer knows that the trust deposited in a norm today will not be violated by the State tomorrow. 
Predictability is an important element of the legal certainty principle. Thus, by prohibiting the retroactive effects of tax law, the Constitution indirectly protects the legal certainty principle itself.

In this regard, because the Brazilian Constitution, unlike others, contains explicit provisions concerning the partial ideals that compose the legal certainty principle (knowability, reliability, and calculability), not only is its basic concept different but also some of its sub-elements must be applied more rigidly than in other legal systems. ${ }^{38}$ As explained above, the ideal of calculability (or predictability) entails that taxpayers must be protected from retroactive tax laws. This means that courts cannot disregard this norm before a concrete case without also jeopardizing the legal certainty principle itself. The same holds true for rules protecting acquired rights, completed legal acts, res judicata and taxable events, which cannot be overruled on public interest grounds, as they can exceptionally be in Germany, Spain, France and Italy. ${ }^{39}$ It was a choice of the Brazilian framers to protect such rights more rigidly, by regulating them through rules, instead of principles or general standards, in the Constitution.

As previously explained, despite the numerous controversies in the legal theory domain, this paper takes the view that rules differ from principles because rules determine what one ought to do in light of all the values that could be at play in a given situation. By determining exactly what conduct should be adopted, they provide for a solution before a controversy arises. The interpreter is not free to assign a meaning to a text that would disregard the intent of the framers of the Constitution. This means that courts are not free to disregard the prescription of the rules set by the framers.

More importantly than that, because of the existence of eternity clauses in the Brazilian Constitution, the guarantees attributed to individuals cannot even be altered by the amendment procedure. The Brazilian Constitution explicitly establishes that constitutional norms which grant individual rights and guarantees cannot be abolished by an amendment to the Constitution. This means that by prohibiting constitutional amendments on specific subjects, article 60, paragraph 4, of the Constitution indirectly assures stability of the legal order:

Article 60. The Constitution may be amended on the proposal of:

I- at least one-third of the members of the Chamber of Deputies or of the Federal Senate;

II - the President of the Republic;

III - more than one half of the Legislative Assemblies of the units of the Federation, each of them expressing itself by the relative majority of its members.

\footnotetext{
38 ÁVILA, Humberto. Certainty in Law. Dordrecht: Springer, 2016. p. 505.
}

39 ÁVILA, Humberto. Certainty in Law. Dordrecht: Springer, 2016. p. 41. 
(...) Paragraph 4. No proposal of amendment shall be considered which is aimed at abolishing:

I- the federative form of State;

II - the direct, secret, universal and periodic vote;

III - the separation of the Government Powers;

IV - individual rights and guarantees. ${ }^{40}$

The purpose of eternity clauses is not the protection of constitutional provisions, but of the principles embodied in them. ${ }^{41}$ In other words, a substantial part of its fundamental principles is likely to remain intact. The guarantee of permanence of those clauses constricts the meaning of the constitutional categories protected by them. This guarantee also prohibits changes that lighten the basic core or weaken the protection of these same constitutional categories. ${ }^{42}$ The main point is that the list of individual guarantees in the Brazilian Constitution is much more extensive than the list of individual guarantees presented in other constitutions. To mention just one example, Article 5 of the Brazilian Constitution deals with Individual and Collective Rights and Duties and has 78 subsections establishing rights and guarantees in the most diverse areas of Law. This article, alone, is more extensive and detailed than several constitutions of other countries. Considering that some constitutional provisions would be better reconstructed as rules, the two major points to be criticized in this brief essay are both the influence of the skeptical theory of interpretation, and the balancing of principles.

\section{THE APPLICATION OF THE SKEPTICAL THEORY OF INTERPRETA- TION TO THE JURISPRUDENCE OF THE BRAZILIAN CONSTITU- TIONAL COURT}

\subsection{Case study: Execution of the sentence after condemnation in the second instance}

The first case to be examined deals with the extension of the presumption of innocence in the Brazilian Constitution. There is a specific constitutional provision (article 5, LVII) stating that: "no one shall be considered guilty before the issuing of a final and unappealable penal sentence". In addition, the Brazilian Code of Criminal Procedure expressly provides the right not to be arrested except as a result of a "final conviction" (article 283, Brazilian Code of Criminal Procedure). As a result of multiple

\footnotetext{
40 Brazilian Constitution in English available in: http://english.tse.jus.br/arquivos/federal-constitution.

41 MIRANDA, Jorge. Manual de Direito Constitucional: Tomo Il. Coimbra: Coimbra Editora, 1998. p. 155.

42 MENDES, Gilmar Ferreira; COELHO, Inocêncio Mártires; BRANCO, Paulo Gustavo Gonet. Curso de Direito Constitucional. 2. ed. São Paulo: Saraiva, 2008. p. 221.
} 
decisions declaring the unconstitutionality of this previous article, two Constitutional Declaratory Actions were filed so that the Supreme Federal Court would examine the constitutionality of the article. More specifically, it was discussed whether it would be constitutional to execute the sentence of imprisonment after the judgment in the second instance, although before a final and unappealable decision.

Notwithstanding the existence of a specific provision in the constitution concerning the presumption of innocence and the legal text that provides for imprisonment only after the final res judicata, the Constitutional Court held that the presumption of innocence should be weighed against other values, such as the punitive interest of the state. The majority of the Justices understood that the result of preserving the presumption of innocence would be unfair and unreasonable. ${ }^{43}$ In this sense, it was understood that consideration should be given, on the one hand, to the presumption of innocence, and, on the other hand, to the need to preserve the system and its reliability. The defendants understood that the beginning of the execution of the sentence after condemnation in the second instance is an offense against the constitutional provision that guarantees the right of anyone not to be found guilty until the final sentence of conviction. Even if appeals to the higher courts (special appeal to the Superior Court of Justice and extraordinary appeal to the Supreme Federal Court) do not have a suspensive effect, the defendants found that the constitutional presumption of innocence until after the res judicata should remain valid.

The Constitutional Court, however, concluded that the presumption of innocence does not prevent imprisonment resulting from a judgment which, on appeal, confirms conviction. The majority of the Court recognized that article 283 of the Criminal Procedure Code does not prevent the beginning of execution of the sentence after conviction in the second instance. As stated by Justice Teori Zavascki, every person charged with an offense has the right to be presumed innocent until found guilty according to law and in a public process in which all the necessary guarantees for his or her defense are ensured. According to Zavascki, before a criminal sentence is issued, it is necessary to maintain doubts about any conduct contrary to the legal system, and thus to the conduct of the accused. For all intents and purposes, but especially as regards the burden of proving the incrimination, the presumption of innocence must prevail. Even if an individual is convicted, the guilty verdict that results from the evidence produced in an adversarial procedure during a criminal proceeding is subject to review by a higher court, if there is an appeal. Usually it is in this appeal that the examination of the facts and evidence of the case are definitively exhausted, with the determination, when appropriate, of the criminal responsibility of the accused. The appeal court represents

43 BRAZIL, Supremo Tribunal Federal, Medida Cautelar na Ação Direta de Constitucionalidade n. 43, Relator Ministro Edson Fachin, Tribunal Pleno, julgado em 05/10/2016. 
the double degree of jurisdiction and reviews the judicial decision in its entirety. The court has discretion to address all matters adduced in the criminal action, whether or not they have been judged by the original court. The defendant is guaranteed the right of access, in full, to this second degree court. ${ }^{44}$ According to the majority of the Justices, except for the criminal review, it is in the ordinary courts that the possibility of examining facts and evidence is exhausted and, in that respect, the very determination of the criminal responsibility of the accused is decided.

The majority of the Justices of the Brazilian Constitutional Court understood that appeals of an extraordinary nature are not part of the right to a double degree of jurisdiction, because in these appeals the Courts do not have the power to debate over factual-probative matters. Thus, the Justices emphasized that after the judgment of the second instance there is the exhaustion of the factual analysis of the case. Therefore, the execution of a sentence pending an extraordinary appeal does not compromise the essential core of the presumption of non-culpability insofar as the accused was treated as innocent in the course of the ordinary criminal proceedings; and the rights and guarantees inherent therein were observed, as well as the evidentiary rules and the current accusatory model. According to the decision: "The community wants a response and wants to get it with a reasonable length of process".45

\subsubsection{The constitutional provision and its interpretation}

There is a specific constitutional provision dealing with the presumption of innocence. It is stated as follows:

\section{CHAPTER I - Individual and Collective Rights and Duties}

Article 5. All persons are equal before the law, without any distinction whatsoever, Brazilians and foreigners residing in the country being ensured of inviolability of the right to life, to liberty, to equality, to security and to property, on the following terms:

(...) LVII - no one shall be considered guilty before the issuance of a final and unappealable penal sentence;

In addition, the Brazilian Code of Criminal Procedure establishes an explicit provision regarding the right not to be arrested except as a result of a "final conviction" (article 283):

44 BRAZIL, Supremo Tribunal Federal, Medida Cautelar na Ação Direta de Constitucionalidade n. 43, Relator Ministro Edson Fachin, Tribunal Pleno, julgado em 05/10/2016, p. 109-140.

45 BRAZIL, Supremo Tribunal Federal, Medida Cautelar na Ação Direta de Constitucionalidade n. 43, Relator Ministro Edson Fachin, Tribunal Pleno, julgado em 05/10/2016, p. 109-140. 
Article 283. No one may be arrested except when caught carrying out a criminal act, by a written decision issued by the competent judicial authority as a result of a final criminal conviction, or in the course of a criminal investigation or criminal proceedings, by virtue of a temporary or preventive arrest warrant.

The case examined by the Brazilian Constitutional Court dealt exactly with the constitutionality of this article of the Code of Criminal Procedure. The question before the Court was: what is the extension of the presumption of innocence for the purpose of the execution of a sentence? The answer to that question, therefore, depended on the interpretation to be given to the constitutional provision on the presumption of innocence (article 5, LVII). This constitutional provision is characterized as a rule with closed antecedent. ${ }^{46} \mathrm{~A}$ rule with a closed antecedent is a rule that exhaustively lists the hypothesis in the presence of which legal consequences are produced, without establishing any kind of exception for its non-application. This norm could be reconstructed as follows: "If there is no final and unappealable sentence (the hypothesis), then no one shall be considered guilty (consequence)." It is a closed rule precisely because it does not admit any exception to its hypothesis.

This disposition is not a principle. It is descriptive and specific; it directly regulates the conduct to be adopted; and its application requires the evaluation of correspondence. Once again, without a final and unappealable sentence (hypothesis), no one shall be considered guilty (consequence). Principles, as mentioned before, are finalistic norms, which do not directly regulate the conduct to be adopted. The generic character and the application of principles require a correlative evaluation between the state of things to be promoted and the effects of the conduct. ${ }^{47}$ The Brazilian Constitution could have opted for establishing the presumption of innocence as a principle to be promoted in its maximum possible effectiveness. It did not do so, however.

These considerations are fundamental to this essay. The reading of the constitutional provision shows that there is no ambiguity with regard to the words used by the Constitution. The literal meaning of the terms used reveals that defendants could not be imprisoned until all their appeals were final. This conclusion is the result of the literal interpretation of this provision. As pointed by Schauer, it is obvious that language is a human creation, and that the rules of language are contingent, in the sense that they could differ from society to society. But these factors of artificiality and contingency do not deny the short-term, or even intermediate-term, non-contingency of meaning. The distinctive feature of rules lies in their ability to be formal, to exclude factors from

46 GUASTINI, Riccardo. L'interpretazione dei documenti normativi. Milano: Giuffrè, 2004. p. 201; LEBEU, Martin. De l'interpretation stricte des lois - essai de méthodologie. Paris: Defrénois, 2012. p. 57.

47 BARBERIS, Mauro. Una filosofia del Diritto per lo stato costituzionale. Torino: G. Giappichelli Editore, 2017,.p. 91; ÁVILA, Humberto. Teoria dos Princípios. 18. ed. São Paulo: Malheiros, 2018, p. 102. On the contrary, by all: ALEXY, Robert. Theorie der Grundrechte. 3 ed. Frankfurt am Main: Suhrkamp, 1996. p. 75 e ss. 
consideration in the particular case: insofar as formalism disables some decision- makers from considering certain factors that may appear important to them, it allocates power to some decision-makers and away from others. ${ }^{48}$

Schauer's argument for formalism is linked to the notion of rules and literalism, which constrains the judge even if he or she does not agree with the result of the application of the rule in the concrete case. Rules have the purpose of coordination and knowledge, giving to all the knowledge about the unique guideline to be applied to a certain situation..$^{49}$ One of the greatest virtues of the Rule of Law doctrine, according to Schauer, is precisely the fact that it is bound to take rules seriously, because the State retains an irreducible formalism by doing so. Sometimes, however, the Rule of Law creates injustices in the concrete case. Formalism is one of the central aspects of what makes Law distinctive. ${ }^{50}$ Hence the importance of the actual text, because it will ensure there is no discrepancy between the understanding of the recipient-interpreter of the rule and its operator. In a similar sense, according to Alexander, formalism would be the adherence to normative prescriptions without the appeal for the reasons behind these prescriptions in the concrete case. This formalistic view, therefore, is concerned with the form/validity of the prescription, rather than with its substantive content or its purposes: the norm must be opaque, in the sense of barring the interpreter from considering other aspects that could have been relevant to the decision, in order to create reasons to act independently of its presupposed goals..$^{51}$

In what concerns the case analyzed in this essay, the language used by the Constitution to establish fundamental rights and, most importantly, to protect against the fact that "no one shall be considered guilty before the issuance of a final and unappealable penal sentence", indicates that the framers prescribed a rule concerning what the State shall not do (i.e., consider a person guilty before the issuance of a final and unappealable penal sentence). This, in its turn, means that if the constitutional norm is to have any effect, it must be interpreted and applied in a formalistic manner. In other words, the Brazilian constitutional provision does not offer any room for considerations by its operators, who should not be able to state anything other than that the provision expresses a direct rule, without ambiguities, and its terms reflect considerations already anticipated by the Constitution. More explicitly, the presumption of innocence should have precedence over the effectiveness of criminal convictions still subject to appeal.

48 SCHAUER, Frederick. Formalism. The Yale Law Journal, vol. 97, n. 4, p. 509-548, mar. 1999, p. $524 ; 543$. SCHAUER, Frederick. Thinking like a lawyer: a new introduction to legal reasoning. Cambridge: Harvard University Press, 2009. p. 18.

49 SCHAUER, Frederick. Formalism. The Yale Law Journal, vol. 97, n. 4, p. 509-548, mar. 1999. p. 543.

50 SCHAUER, Frederick. Thinking like a lawyer: a new introduction to legal reasoning. Cambridge: Harvard University Press, 2009. p. 31; 35.

51 ALEXANDER, Larry. With Me, It's All er Nuthin: Formalism in Law and Morality. The University of Chicago Law Review, [s.I.], vol. 66, n. 3, p. 530-565, jun./ago. 1999. p. 534. 


\subsubsection{The arguments of interpretation applied in the Court's decision}

Despite the considerations previously made on the interpretation of the constitutional provision regarding presumption of innocence, the Brazilian Constitutional Court has opted for other interpretative arguments. The reading of the decision of the Constitutional Court shows that the nature of the constitutional provision as a rule was defeated. The Court held that presumption of innocence would be a principle, which would depend on consideration of other rights to be applied in the particular case. At least three arguments used by the constitutional decision should be highlighted.

The first is the teleological argument, linked in this case to the reasonableness of the length of the process and proportionality of the measure. In this case, Justices used reasonableness as a tool or as a justification for the balancing test. According to Zorzetto, the balancing test is another primary way of applying reasonableness. For her, balancing is just a metaphor, since no balance exists in law. Principles, values, goods and interests are regularly balanced in light of reasonableness: this idea is used as an imaginary criterion to weight these objects. In reality, however, the measure is obviously only a discretionary evaluation. ${ }^{52}$ The balancing made by the Justices is clear in the following excerpt of the decision:

Within that space that the Constitution grants the interpreter a margin of conformation that does not go beyond the limits of the textual frame, the best hermeneutical alternatives are perhaps in principle those that lead to reserve to this Supreme Court primarily the protection of the constitutional legal order, to the detriment of an unattainable mission of solving concrete cases. For this reason, I interpret the rule of art. 5th, LVII, of the Constitution, according to which "no one shall be held guilty until a final judgment has been passed", deeming it necessary to construe it in accordance with other constitutional principles and rules which, taken in consideration with equal emphasis, do not allow the second which only after the extraordinary instances have been exhausted, can begin the execution of the custodial sentence. ${ }^{53}$

In fact, the majority of the Brazilian Constitutional Court used reasonableness in the case as a tool to achieve another result - not the one required by the constitutional provision. The idea of reasonableness was used as a pretext for balancing values that would be counterposed: on the one hand, presumption of innocence and, on the other hand, the reasonable length of process and the necessity for enforcement of convictions. As previously mentioned, the decision proclaimed that "the community wants a response and wants to get it within a reasonable length of process".

52 ZORZETTO, Silvia. Reasonableness. The Italian Law Journal, [s.I.], vol. 1, n. 1, p. 107-139, 2015, p. 133.

53 BRAZIL, Supremo Tribunal Federal, Medida Cautelar na Ação Direta de Constitucionalidade n. 43, Relator Ministro Edson Fachin, Tribunal Pleno, julgado em 05/10/2016, p. 35. 
The second argument to be highlighted is the comparative argument with other jurisdictions. In this regard, Justice Teori Zavascki, for example, emphasized that the execution of a sentence pending extraordinary appeals does not compromise the essential core of the presumption of non-culpability insofar as 1) the accused was treated as innocent in the course of the ordinary criminal proceedings, 2) the rights and guarantees inherent therein were observed, 3 ) the evidentiary rules and the current accusatory model were followed. The Justice cited a study of comparative Law to show that in no country in the world, after observing the double degree of jurisdiction, is the execution of a conviction suspended, awaiting a possible Supreme Court referendum. He listed, for example, the laws of England, Canada, Germany, France, Portugal, Spain and Argentina. Thus, the interpretation given by other legal systems to their constitutional provisions on the presumption of innocence (in some cases, without any constitutional prescription on this subject) served as an argument to determine what would be the correct way of interpreting the Brazilian constitutional provision. ${ }^{54}$

Both arguments undertaken by the Justices of the Brazilian Supreme Court are interesting because they show that the Brazilian constitutional text was disregarded in the name of arguments regarding other constitutional systems. Reasonableness therefore functions here as a mechanism of defeasibility of the expressed constitutional rule, in order to allow a (morally) more correct result from the point of view of a majority of Brazilian Justices. Such use, however, is in line with the theory of reasonability adopted by Siches, in the sense that reasonableness serves as a technique that allows Law to promote values, especially in the resolution of the concrete case. Siches clarifies that such use could not be regarded as arbitrary. The application of principles or values in discretionary acts should not be confused with arbitrariness, according to the author. ${ }^{55}$

The third argument to be highlighted is the consequentialist argument. To argue the reasons why the effectiveness of the conviction should prevail over the presumption of innocence, some Justices used the argument that, if it were not so, the Brazilian Penal System would not be effective. The argumentation in this sense was corroborated by the use of a series of examples of practical cases in which the Brazilian Judicial System was slow to solve a controversy. Justice Teori Zavascki, for example, mentioned the convictions of Brazil in the Inter-American Court of Human Rights support the idea that the Brazilian Penal System is ineffective. ${ }^{56}$ Such a scenario would demonstrate the lack of protection of victims and the need to adopt other measures to ensure the

\footnotetext{
54 BRAZIL, Supremo Tribunal Federal, Medida Cautelar na Ação Direta de Constitucionalidade n. 43, Relator Ministro Edson Fachin, Tribunal Pleno, julgado em 05/10/2016, p. 109-140.

55 SICHES, Luís Recasens. Introducción al Estudio del Derecho. 12. ed. México: Editorial Porrúa, 1997. p. 108109.

56 BRAZIL, Supremo Tribunal Federal, Medida Cautelar na Ação Direta de Constitucionalidade n. 43, Relator Ministro Edson Fachin, Tribunal Pleno, julgado em 05/10/2016, p. 109-140.
} 
effectiveness of the fundamental rights violated by the criminal act. Similarly, Justice Luís Roberto Barroso also stated that "the Brazilian penal system has not worked properly. The possibility that the defendants await the res judicata of the special and extraordinary appeals in freedom, only then initiating the execution of the sentence, weakens too much the protection of the juridical values protected by criminal law and the very trust of society in criminal justice".57 The Justice also used paradigmatic cases not resolved by the Brazilian Judiciary to justify the consequences of the interpretation in the opposite direction.

\subsubsection{Criticism of the decision}

This judgment, therefore, illustrates the application of reasonableness as a moral correction to Law. Since the Justices, from their moral point of view on the idea of punishment, did not agree with the consequences of applying the presumption of innocence rule, the constitutional guarantee was derogated in the name of the reasonableness of the length of the criminal process and the social interest of punishing the condemned - still without a final res judicata. This scenario shows the growth in Brazil of the neo-constitutional doctrine, which promotes reasonableness as an instrument capable of providing room for moral aspects in Law.

The criticism that seems pertinent to this understanding, however, concerns the fact that the choice of either applicable values or the one which will come to prevail in case of balancing occurs in an arbitrary way, in the sense that it is not justified by any legal rule. The case decided by the Supreme Federal Court exemplifies this situation. The Constitution presented an explicit rule of presumption of innocence and provided for the impossibility of enforcing the penalties before the final sentence of conviction. Even so, most Justices considered that the principle of reasonable length of the criminal procedure and the need to comply with sentences should prevail. The reasoning used to reach this decision is justified only from the moral point of view, which shows that reasonableness here is only a pretext for justification of the decision, albeit to the detriment of the constitutional text.

An article written by Cuono deals with the use of reasonability as an instrument for the introduction of moral arguments in Law. According to the author, one of the possible meanings of reasonableness is exactly that of acting as a boundary between differentiation and discrimination. The existence of a "sufficient reason" is mentioned by some authors as the criterion for this differentiation, which involves the concept of reasonableness. ${ }^{58}$ The author himself, however, points out that these perspectives have

57 BRAZIL, Supremo Tribunal Federal, Medida Cautelar na Ação Direta de Constitucionalidade n. 43, Relator Ministro Edson Fachin, Tribunal Pleno, julgado em 05/10/2016, p. 109-140.

58 CUONO, Massimo. Entre arbitrariedad y razonabilidad. Hacia uma teoria crítica del neocostitucionalismo. Eunomía. Revista en Cultura de la Legalidad, [s.I.], n. 3, p. 44-60. 2012-2013. p. 48. 
not been used by the authors of neo-constitutionalism. Authors like Alexy and Dworkin prefer two other perspectives for reasonableness.

On the one hand, there is the idea of reasonableness as morality, that is, as an attitude according to practical reason, in the sense of good or morally just. Alexy's theory rightly defends this perspective, insofar as every legal system has a claim to correctness. ${ }^{59}$ Thus, every situation of conflict between principles should be solved through consideration that would ensure a fair result from the moral point of view. On the other hand, there is the idea of reasonableness as flexibility, also present in the neo-constitutional doctrine, and linked to the discretion of the judge to find solutions to the controversies through moral arguments in the interpretation of fundamental rights according to the social context of their application. ${ }^{60}$

Cuono, however, is quite critical of this approach to reasonableness as an instrument for giving room to moral arguments in Law. According to him, reasonableness is not necessarily bound to morality. Reasonableness lies within the idea of Rule of Law and its guarantees, such as constitutional rigidity and constitutionality control, without the need for it to be linked with an idea (abstract and indefinite) of moral justice. ${ }^{61}$ The author seems correct in his criticism. Both the idea of reasonableness as equivalence and the idea of reasonableness as congruence do not depend on a moral judgment about Law. They are requirements of the idea of Rule of Law and not of moral judgments of behavior.

The criticism to be presented regarding the decision of the Federal Supreme Court concerns the skeptical stance adopted with regard to the constitutional text. As discussed, the constitutional provision on presumption of innocence was straightforward and clear with respect to the inexhaustibility of any kind of exception in its application. In spite of the existence of this clear and explicit rule, the Brazilian Constitutional Court overruled in the name of the conception of justice adopted by the majority of its Justices. This position, however, is detached from the framers' choice regarding the establishment of fundamental rights in the Brazilian Constitution. There is a proportional relationship here: the greater the restriction of fundamental rights involved, the greater must be the respect for the preliminary meaning of the text of the provision, since only laws can limit rights - not the Administration or the Judiciary. This means that the linguistic and systematic arguments, as immanent institutional arguments, that is, constructed on the basis of the current legal order, from their textual and contextual

59 ALEXY, Robert. The Dual Nature of Law. Ratio Juris, [s.l.], vol. 23, n. 2, p. 167-182, jun. 2010, p. 168; ALEXY, Robert. Constitutional Rights and Proportionality, Revus - Journal for Constitutional Theory and Philosophy of Law, [s.l.], vol. 22, p. 51-65, 2014.

60 CUONO, Massimo. Entre arbitrariedad y razonabilidad. Hacia uma teoria crítica del neocostitucionalismo. Eunomía. Revista en Cultura de la Legalidad, [s.I.], n. 3, p. 44-60. 2012-2013. p. 49.

61 CUONO, Massimo. Entre arbitrariedad y razonabilidad. Hacia uma teoria crítica del neocostitucionalismo. Eunomía. Revista en Cultura de la Legalidad, [s.l.], n. 3, p. 44-60. 2012-2013. p. 56. 
language, have a prominence in this type of situation. ${ }^{62}$ There is a prima facie priority of the reasons for authority. ${ }^{63}$

The main reason for this stems from the very existence of a Rule of Law, in which democratic values are represented by the participation of citizens in the decisions that will govern their lives and society as a whole, and especially those which limit their rights as free citizens. Respect for the text of the provision or, more specifically, for the language chosen by the legislator, means respect for democratic values. ${ }^{64}$ As pointed by Aarnio, the prominence of this criterion is to value the role of the Legislative Power and to promote the democratic ideals attached to it, as a form of respect for authority: if one who holds authority imposes a provision in a certain way, necessarily using a certain language to do so, its authority is not respected unless one reads the text in the language in which it was recorded. In short, the idea of the text of the provision as the starting point is supported by the values of democracy and the Constitutional State. ${ }^{65}$

The Golden Rule according to which there is a prima facie priority of the ordinary meaning of texts for interpretation - unless it produces such an inconsistent, absurd or inconvenient result that it convinces the Court that the intention of the norm was not to be applied in its ordinary meaning -, is a consequence of this understanding. 66 The rule of English influence is linked to the political-legal value it serves, namely, the promotion of Rule of Law and the separation of powers, in respect to Parliament's democratic decisions. ${ }^{67}$ This rule demonstrates the presumption of application of the linguistic criterion, that is, of the ordinary meaning of the texts, as a general rule. And this presumption, again, grows as the restriction of fundamental rights grows - hence it is even stronger in the rules regarding tax collections and penalties in Tax Law and Criminal Law, than in other branches of Law. This means that the interpreter who will analyze these provisions must refrain from using arguments capable of amplifying their extension to encompass situations not foreseen in the ordinary interpretation of the text used. Thus, behind what is usually described with disapproval as "formalist"

62 ÁVILA, Humberto. Argumentação jurídica e a imunidade do livro eletrônico. Revista de Direito Tributário, São Paulo, vol. 79, p. 163-183, 2001. p. 179.

63 ALEXY, Robert. The Dual Nature of Law. Ratio Juris, [s.I.], vol. 23, n. 2, p. 167-182, jun. 2010. p. 179.

64 AARNIO, Aulis. Essays on the Doctrinal Study of Law. Dordrecht: Springer, 2011. p. 152.

65 AARNIO, Aulis. Essays on the Doctrinal Study of Law. Dordrecht: Springer, 2011. p. 152.

66 In this sense, LORD BLACKBURN in the case River Wear Commissioners v. Adamson (1987) 2 App. Cas. 743 at. p. 764-765:"(...) that we are to take the whole statute together, and construe it all together giving the words their ordinary signification, unless when so applied they produce an inconsistency, or an absurdity or inconvenience, so great as to convince the Court that the intention could not have been to use them in their ordinary signification".

67 BANKOWSKI, Zenon; MACCORMICK, Neil. Statutory Interpretation in the United Kingdom. In: MACCORMICK, Neil; SUMMERS, Robert. (Org.). Interpreting Statutes - A Comparative Study. Aldershot: Dartmouth, 1991. p. 359-406. (382-383). 
or "legalistic" approaches are approaches to interpretation that actually bring in value ratios of high regard. ${ }^{68}$

On the one hand, behind the linguistic interpretation there is the goal of preserving the clarity and precision of the legislative language and the principle of justice that prohibits retrospective judicial rewriting of the words chosen by the legislator. ${ }^{69}$ On the other hand, behind the systematic argument exists the principle of rationality based on the value of coherence and integrity of the legal system. The main rule, therefore, is that precedence must be given to arguments that go back to the principles of the Rule of Law and democracy, thereby giving priority to linguistic and systematic arguments in detriment of others. ${ }^{70}$

The consequentialist argument must also be criticized. Consequentialist arguments or arguments arising from the interpreter's own ethical judgment, in the sense of what would be fairer or more correct in a particular situation, are non-institutional arguments, that is, arguments that do not refer to the institutional modes of the existence of law. According to Ávila, these arguments appeal to any element other than the legal system itself, since they are purely pragmatic arguments that depend on a judgment, made by the interpreter, from his or her own economic, political and/or ethical points of view. ${ }^{71}$ The author, dealing with consequentialist arguments when attributing prospective effects to unconstitutionality rulings, insists on the fact that this kind of argument inverts the logic of law itself. The structure of a legal rule consists of a hypothesis and a consequence. The consequentialist argument assumes that the interpreter can foresee that if he or she acts in a given manner, a given consequence will follow. To judges, this hypothetical-conditional structure serves as a compass for their decisions: When $X$, and $X$ was done, I ought to decide $Y$; and when $X$, and not- $X$ was done, then I ought to decide $Z$. Ávila points that, in this normative scheme, the decision the judge makes is not a product of comparing the effect programmed by the legislator and the effect the judge intends to program, nor is it the result of replacing one effect with another. The judge does not use the effects as a deciding reason and does not compare the effect of the conditional program with other effects. The normative efficacy is that which was previously defined by the legislator. The decision alters precisely this rationale for decision-making by equating the decisions in both cases: "When $X$, and $X$ was done, I decide $Y$; but when $X$, and not- $X$ was done, I also decide $Y !^{\prime 72}$

68 MACCORMICK, Neil. Rhetoric and the Rule of Law. New York: Oxford University Press, 2005. p. 127.

69 MACCORMICK, Neil. Rhetoric and the Rule of Law. New York: Oxford University Press, 2005. p. 139.

70 ÁVILA, Humberto. Juristische Theorie der Argumentation. In: HELDRICH, Andreas. et al. (Org.). FS für ClausWilhelm Canaris zum 70. Geburtstag. München: Beck, 2007. p. 963-989.

71 ÁVILA, Humberto. Argumentação jurídica e a imunidade do livro eletrônico. Revista de Direito Tributário, São Paulo, vol. 79, p. 163-183, 2001. p. 174.

72 ÁVILA, Humberto. Certainty in Law. Dordrecht: Springer, 2016. p. 410. 
This is exactly the situation analyzed in the case judged by the Supreme Federal Court. Even though the constitutional text is explicit in stating that no one can be treated as guilty (and therefore deserving of the corresponding penalty) before the final and unappealable decision of the criminal proceedings, the decision affirms the exact opposite: even without a final and unappealable decision, the defendant may be found guilty. Opening up a decision to the consideration of consequences, however, as Machado Derzi points, "presupposes yet another infinite series of possibilities open to the choice of the applier of law as to the economic or sociological theory to adopt, because there is no unanimity either in the explanatory sciences or in the sciences of the spirit that can securely predict the effects that will be unleashed."73 For this reason, a consequentialist theory of decision-making without rigorous delimitation of the desirable consequences is entirely incompatible with the legal certainty principle, given the absurd uncertainty produced by its deployment. ${ }^{74}$

\section{CONCLUSIONS}

The case analyzed in this essay demonstrate that the majority of the Justices of the Brazilian Constitutional Court has put aside its role as interpreter of the Constitution in order to impose its vision of justice on the Constitutional System. Such a position is linked to an openness to the derogation of the rules for the promotion of values (especially moral values) considered relevant by the Justices and seems to reflect, to a certain extent, a skeptical attitude towards the interpretation of texts. The analysis undertaken in the paper is relevant in demonstrating how the current Brazilian Supreme Court posture on interpretation is contrary, on one hand, to the Rule of Law doctrine, which seeks to curtail arbitrariness and promote predictability; and, on the other hand, to the ideals pursued by the legal certainty principle. There was an explicit rule, which presented a preliminary meaning that indicated a solution different from the one subsequently adopted by the court. This means that the literal argument, concerning the formulation of the text of the constitutional provision, was rejected or relaxed in the name of values that were considered more important by the Supreme Federal Court. This is a dangerous precedent from the point of view of the Brazilian legal system. The Supreme Federal Court, which should act as guardian of the Constitution, began to read the constitutional text from a political stance, even in matters related to rules that directly protect fundamental rights.

73 MACHADO DERZI, Misabel de Abreu. Modificações da jurisprudência no Direito Tributário. São Paulo: Noeses, 2009. p. 171.

74 MACHADO DERZI, Misabel de Abreu. Modificações da jurisprudência no Direito Tributário. São Paulo: Noeses, 2009. p. 173; 216. 
This relaxation of the rules (and even their defeasibility) affects the legal certainty of all citizens and poses a threat to the Rule of Law doctrine. As pointed by Barberis, the idea that the Law must respect Justice (the claim to correctness in Alexy's doctrine) creates a kind of collapse of Law into the moral: Law becomes superfluous and can always be replaced by the morals of the judges. ${ }^{75}$ According to Ávila, what is essential for the existence of the knowability of law is the existence of rules and exceptions, as long as the exceptions can be perceived using minimally objective and controllable criteria in most cases. However, when an exception is institutionalized, or slowly but steadily transformed into the rule, its addressees no longer know which norm to follow, whether the specific applicable norm, or another one possibly determined by the Judiciary. Ultimately, right and wrong can no longer be clearly distinguished. When that happens, Law loses one of its fundamental functions, which is to generalize and stabilize normative expectations of behavior through the binary code lawful/unlawful76.

This scenario indicates the paradox previously mentioned: from the point of view of fundamental rights, Brazilian citizens have one of the most protective constitutions, since such rights were established by means of constitutional rules, which consubstantiate eternity clauses. However, the protection set forth by those rules is ineffective because of how the Constitutional Court interprets the provisions from which such rules are reconstructed. The result is that citizens are often left unprotected, despite the persistence of the Constitution in determining fundamental rights through rules.

\section{REFERENCES}

AARNIO, Aulis. Essays on the Doctrinal Study of Law. Dordrecht: Springer, 2011.

ALEXANDER, Larry. With Me, It's All er Nuthin: Formalism in Law and Morality. The University of Chicago Law Review, [s.l.], vol. 66, n. 3, p. 530-565, jun./ago. 1999.

ALEXY, Robert. Theorie der Grundrechte. 3 ed. Frankfurt am Main: Suhrkamp, 1996.

ALEXY, Robert. The Dual Nature of Law. Ratio Juris, [s.I.], vol. 23, n. 2, p. 167-182, jun. 2010.

ALEXY, Robert. Constitutional Rights and Proportionality, Revus - Journal for Constitutional Theory and Philosophy of Law, [s.l.], vol. 22, p. 51-65, 2014.

ÁVILA, Humberto. Certainty in Law. Dordrecht: Springer, 2016.

ÁVILA, Humberto. Teoria dos Princípios. 18. ed. São Paulo: Malheiros, 2018.

ÁVILA, Humberto. Argumentação jurídica e a imunidade do livro eletrônico. Revista de Direito Tributário, São Paulo, vol. 79, p. 163-183, 2001.

75 BARBERIS, Mauro. Una filosofia del Diritto per lo stato costituzionale. Torino: G. Giappichelli Editore, 2017. p. 83.

76 ÁVILA, Humberto. Certainty in Law. Dordrecht: Springer, 2016. p. 222-223. 
ÁVILA, Humberto. Eficácia do Novo Código Civil na Legislação Tributária. In: GRUPPENMACHER, Betina. (Org.). Direito Tributário e o Novo Código Civil. São Paulo: Quartier Latin, 2004. p. 61-79. ÁVILA, Humberto. Juristische Theorie der Argumentation. In: HELDRICH, Andreas. et al. (Org.). FS für Claus-Wilhelm Canaris zum 70. Geburtstag. München: Beck, 2007. p. 963-989.

ÁVILA, Humberto. Função da Ciência do Direito Tributário: do formalismo epistemológico ao estruturalismo argumentativo. Revista Direito Tributário Atual, São Paulo, vol. 29, p. 181-204, 2013.

BANKOWSKI, Zenon; MACCORMICK, Neil. Statutory Interpretation in the United Kingdom. In: MACCORMICK, Neil; SUMMERS, Robert. (Org.). Interpreting Statutes - A Comparative Study. Aldershot: Dartmouth, 1991. p. 359-406.

BARBERIS, Mauro. Una filosofia del Diritto per lo stato costituzionale. Torino: G. Giappichelli Editore, 2017.

CHIASSONI, Pierluigi. Tecnica dell'interpretazione giuridica. Bologna: II Mulino, 2007.

CUONO, Massimo. Entre arbitrariedad y razonabilidad. Hacia uma teoria crítica del neocostitucionalismo. Eunomía. Revista en Cultura de la Legalidad, [s.l.], n. 3, p. 44-60. 2012-2013.

DICIOTTI, Enrico. L'ambigua alternativa tra cognitivismo e scetticismo interpretativo. Working Paper 45, Università degli studi di Siena, Siena, p. 3-81, 2003.

FALLON, JR. Richard H. “The Rule of Law” as a Concept in Constitutional Discourse. Columbia Law Review, New York, vol. 97, n. 1, p. 1-56, 1997.

GUASTINI, Riccardo. L'interpretazione dei documenti normativi. Milano: Giuffrè, 2004.

GUASTINI, Riccardo. Distinguiendo - Estudios de teoría y metateoría del derecho. Barcelona: Editorial Gedisa, 1999.

GUASTINI, Riccardo. Interpretar y argumentar. Madrid: Centro de Estudios Políticos y Constitucionales, 2014.

GUASTINI, Riccardo. Nuovi studi sull'interpretazione. Roma: Aracne, 2009.

GUASTINI, Riccardo. Interpretación y construcción jurídica. Legal Interpretation and Legal Construction. Isonomía, [s.I.] n. 43, p. 11-48, out. 2015.

JHERING, Rudolph von. Geist des römischen Rechts auf den verschiedenen Stufen seiner Entwicklung. 5. ed. Leipzig: [s.n.], 1880.

LAPORTA, Francisco J. El Império da la Ley - Una visíon actual. Madrid: Trotta, 2007.

LEAO, Martha. O Direito Fundamental de economizar tributos. São Paulo: Malheiros, 2018.

MACCORMICK, Neil. Rhetoric and the Rule of Law: A Theory of Legal Reasoning. Oxford: Oxford University Press, 2005. 
MACHADO DERZI, Misabel de Abreu. Modificações da jurisprudência no Direito Tributário. São Paulo: Noeses, 2009.

MAZZARESE, Tecla. Enunciato descritivo d'una norma: osservazione su uma nozione imbarazzane. Studi in memoria de Giovanni Tarello, Milano, vol. 2, p. 253-288, 1990.

MENDES, Gilmar Ferreira; COELHO, Inocêncio Mártires; BRANCO, Paulo Gustavo Gonet. Curso de Direito Constitucional. 2. ed. São Paulo: Saraiva, 2008.

MIRANDA, Jorge. Manual de Direito Constitucional: Tomo II. Coimbra: Coimbra Editora, 1998.

RAMÍREZ, Federico Arcos. La seguridad jurídica: una teoría formal. Madrid: Dykinson, 2000.

SCHAUER, Frederick. Thinking like a lawyer: a new introduction to legal reasoning. Cambridge: Harvard University Press, 2009.

SCHAUER, Frederick. Formalism. The Yale Law Journal, vol. 97, n. 4, p. 509-548, mar. 1999.

SEER, Roman. National Report: Germany. In: MEUSSEN, Gerard. (Org.). The Burden of Proof in Tax Law: EATLP International Tax Series, volume 10. Uppsala: EATLP, 2011. p. 127-139.

SICHES, Luís Recasens. Introducción al Estudio del Derecho. 12. ed. México: Editorial Porrúa, 1997.

ZORZETTO, Silvia. Reasonableness. The Italian Law Journal, [s.I.], vol. 1, n. 1, p. 107-139, 2015. 